\title{
Reading Alberto Caeiro's Poems with Anthropocene Eyes
}

Tatiana Massuno

Ph.D. in Comparative Literature, Universidade do Estado do Rio de Janeiro, Brazil 2018 Study of the US Institute on Contemporary American Literature alumna

\begin{abstract}
The term "Anthropocene" proposed by Crutzen and Stoermer in 2000 names a new geological epoch, that endows humans with geological agency. The advent and acceptance of this new geological epoch begs the revision of Modernity's cherished concepts and the reframing of the so-called modern constitution, the Great Divide, as conceived by Bruno Latour. Modernity's wall, the one that separates humans and non-humans, shows its cracks in the Anthropocene. Literature, however, long ago, had anticipated the need for rethinking our relationship with Nature, especially with regards to the subject/object dichotomy. Alberto Caeiro, Fernando Pessoa's heteronym, claims that Nature had been neglected by all poets and thinkers, as he is the first poet to have noticed it. The present article aims at, therefore, reading Caeiro's poems with Anthropocene eyes so that the subject/object dichotomy, one of the pillars of Modernity, can be better investigated.
\end{abstract}

Key words: Anthropocene, Modernity, Subject, Object, Nature.

Correspondence | Tatiana Massuno, tatiana.massuno@gmail.com

Citation | Massuno, T. (2019) Reading Alberto Caeiro's Poems with Anthropocene Eyes. Journal of Big History, III(2); $63-72$.

DOI | http://dx.doi.org/10.22339/jbh.v3i2.3240

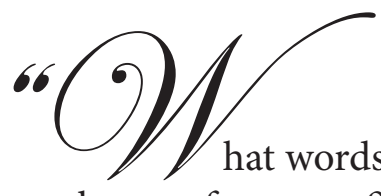

or heart of man suffice to comprehend?" (Paradise O Lost, BK. VII, 113-14), Raphael asks himself, acknowledging the burden of the task at hand: warning Adam and Eve about Lucifer. Raphael's questions then reveal the disparity between two realms, namely that of man and that of celestial beings. How could he, an angel, speaking a celestial language that differed from that of man's disclose the creation of the world and the existence of Paradise to unfit ears? How could the father of mankind be able to comprehend events so distant from his daily life? Events unheard of, such as the war in Paradise? Two different realms, languages, constitutions.

When Raphael perceives Adam's curiosity, his tendency to look for God's traces on Earth, as if there were a correspondence between the visible and the invisible realms, he adds: "But Knowledge is as food, and need no less/ Her Temperance over Appetite, to know/ In measure what the mind may well contain/ Oppresses else with Surfet, and soon turns/ Wisdom to Folly, as Nourishment to Winde" Paradise Lost (BK.
VII, 116-20). The comparison between Knowledge and food once more leads to the main problem: human constitution. Human understanding is limited, circumscribed by its constitution. That which is ungraspable, unimaginable, or even inexplicable stems from human limitation. There is a certain kind of knowledge, though, which maybe humanly acceptable: in Raphael's terms, what the mind can contain. The mind, thus, as well as the stomach, is likened to a container, since its physical capacity is at play. The limitations are physical, constitutional. Surpassing the limit, trying to know more than the mind could physically sustain would mean turning "Wisdom to Folly". What's more, not only does the word "contain" emphasize the physical limitations of the mind, but also its control qualities. Humanly fit knowledge is the one the mind can control. It is no wonder, then, that Raphael is allowed to answer some of Adam and Eve's questions but with a condition: "I have receav'd, to answer thy desire/ Of Knowledge within bounds" Paradise Lost (BK. VII, 119-20). Limits, limitations, bounds: the world before the fall was a limited world, 
it was living "within a circle or behind a line", as Stanley Cavell would say (CAVELL, 1988, p. 49).

After listening attentively to Raphael's narration, Adam summarizes his teachings:

How fully hast thou satisfi'd mee, pure Intelligence of Heav'n, Angel serene, And freed from intricacies, taught to live, The easiest way, nor with perplexing thoughts

To interrupt the sweet of Life, from which God hath bid dwell farr off all anxious cares, And not to molest us, unless we our selves Seek them with wandring thoughts, and notions vaine.

But apte the Mind or Fancie is to roave Uncheckt, and of her roaving is no end; Till warn'd, or by experience taught, she learn That not to know at large of things remote From use, obscure or suttle, but to know That which before us lies in daily life, Is the prime Wisdom, what is more, is fume, Or emptiness, or fond impertinence, And renders us in things that most concerne Unpractis'd, unprepar'd, and still to seek Paradise Lost( BK. VIII.180-97)

The prime wisdom would thus be not letting the mind rove, by not allowing it to entertain itself with matters far from reach. A human mind should stay away from intricacies or from things remote by adhering to what laid before it in daily life. Interestingly enough, Raphael's words point to the need to abstain from imagining worlds that could not be seen, to abstain from trying to find similarities between the visible and the invisible domains. The limits, limitations, bounds also meant that there were different worlds: Eden and Paradise, visible and invisible, human and divine that did not correspond to one another. Therefore, there is a separation hence from what happens above and what happens below. How far from the medieval world are we!

Catherine Martin in Ruins of Allegory: Paradise Lost and the Metamorphosis of Epic Convention studies how Paradise Lost departs from both the epic tradition as well from the normative allegory practiced by Dante and Spenser. The author studies Milton's epic from Benjamin's perspective, that is, from the perspective of the baroque allegory. While normative allegory's structure would be that of the synecdoche - a part representing the whole, which would result in the search of universals from natural correspondences; in Paradise Lost the allegory stems from a more contingent rhetoric figure: the metonym. "what if Earth / Be but the shaddow of Heav'n, and things therein / Each to other like, more then on earth is thought?" Paradise Lost (BK. V, 574-76), the question what if inscribes the relationship between Heaven and Earth in the domain of uncertainty. What if one is the shadow of the other? What if it is not? How does one ascertain the rules that govern such relationship? One cannot. Besides, the relationship, that of being the shadow, inhibits the search for correspondences, analogies. The part does not represent the whole anymore, the relationship between part and whole is more contingent than thought, above and below are contingently separated.

Throughout his narration Raphael is pretty clear about his objectives: to show Adam and Eve how to avoid being expelled from Eden. This meant respecting the boundaries, accepting human's constitution, coming to terms with the fact that what is humanly acceptable is within bounds. In other words, living in Eden was living behind a line. What if they crossed that line? Then they would turn "Wisdom to Folly". Because crossing the line would mean the realization that Eden was not the world, that there was an elsewhere, it would mean being exposed to "the vulnerability of knowledge" (CAVELL, 1988, p. 49). Prior knowledge would not be sufficient to account for this new world beyond the line:

The irony here, then is that this rationalist age of renewed certitude in philosophy, science and religion is actually the beginning of a greater age of doubt that prophetic poets like 
Milton (as well as anti-Cartesian philosophers like Pascal) could begin to foresee in advance (MARTIN, 1998, p. 5).

Raphael knowingly or not exposes both the conditions for certainty and its frailty. Certainty was therefore conditioned by the need of separation. As long as human and divine realms remained separated and the explosion of correspondences was restrained, as long as men lived behind the line, mankind could live in the Eden of clear and distinct ideas. Reaching for the unconditioned, however, would result in Wisdom turning to Folly.

Catherine Martin's assertion that Paradise Lost entailed a departure from normative allegory's tradition unveils its different world view. Not that of correspondences anymore, or in Foucault's terms, not a world where words and things coincided, not a world, therefore, imbued with divine signs, traces ready to be deciphered; but one that demanded separation between the humans and the divine, between words and things, and what else?

Paradise Lost was written on the onset of Modernity, a time when not only Descartes' clear and distinct ideas were shaping the conception of knowledge but also when his cogito was paving the way for what Hegel would later call subjectivity, the principle that governed Modernity. Even though, as Bruno Latour states in We have never been modern, there are as many thinkers as versions of Modernity, they all converge in one aspect - that of the passage of time (LATOUR, 1993, p.10). Modernity entailed a new regime, a rupture, a revolution in time. Wasn't it what Hegel meant when he conceived the modern times? Whose principle differed from that of pre-moderns'? In the sense that it was ruled by freedom and reflection? No wonder does human history seem to have one thread: "freedom has been the most important motif of written accounts of human history of these two hundred and fifty years" (CHAKRABARTY, 2009, p. 208). As if the history of men were an account of mankind's increasing freedom along the years, as if each new modern epoch would break away from traditions, freeing itself from the restraints of past times. "time's irreversible arrow" (LATOUR, 1993, p. 10), leading towards progress, freeing mankind from obscurantism and the mishmash of worlds?

Modernity, nonetheless, is far from being defined by the advent of humanism or even by the sciences. Its strengths and weaknesses derive, however, from what characterizes the modern constitution, that is, the Great Divide. In Latour's terms, the Great Divide is the separation between natural and social worlds, between human and non-humans. While the pre-moderns had conceived the world by means of hybrids, acknowledging their existence and limiting their proliferation; the moderns, on the other hand, as their opponents as the creators of a new paradigm that would, eventually, be the model to be established worldwide, didn't conceive the world from the same perspective. In this sense, the medieval world, the world of analogies, of the correspondences between what happens above and what happens below; world, thus, where the divine trace could be sought, where words were things, gives rise to a different kind of allegory, that of Benjamin's, that promulgates for the arbitrariness of the sign: the coincidence between visible and invisible, between words and things was no longer possible. Benjamin's allegory reveals that the relationship between things and words was arbitrary, granted and never essential. Modern constitution, therefore, advocates for the separation of worlds. The advent of humanism was, though, asymmetrical, insofar as it did not result in the creation of nonhumanism that, following the lines of modern constitution's logics would be its contemporary. This, however, begs the question: what would be the limit of such separation?

In the beginning of his essay, Bruno Latour anticipates the argument to be pursued: the proliferation of hybrids throughout modernity, the fact that modern constitution, actually, allows and even enables the same proliferation that it was supposed to restrain. The daily articles that open the essay seem to set the tone for 
the issue to be developed: the biological had entered the political field, the separation between humans and non-humans was just a fallacy concealed by means of purification and mediation. Humans and nonhumans had never been apart, then, as hybridization always took place, especially during the so-called modern times. That is, we have neveractually been modern. According to Latour, the separation between humans and non-humans, Society and Nature, or even between subject and object was what characterized our conception of modernity. Wasn't it Hegel who understood that subjectivity was the principle that governed the modern times? Wasn't it Kant who claimed that the thing-in-itself was beyond the limits of our understanding? Or even Heidegger, later, that stated that science was not able to think the Being? Latour would say that all these philosophical thoughts revolved around the same problem: the irreconcilable separation between humans and non-humans. So I ask, does being modern mean living behind a line or within a circle? Behind the line that separated humans and non-humans? What if the line was crossed? Would Wisdom be turned into Folly?

I am the first poet to remember that Nature exists, says Alberto Caeiro, Fernando Pessoa's heteronym ${ }^{1}$. Curiously, Caeiro's originality resided in claiming that a stone was nothing but a stone or that a flower should be understood as it was: a flower and nothing else. Alberto Caeiro, the master of Pessoa's heteronyms, whose poems were clearly distinct even from that of Pessoa's orthonym, both in style and themes, the complicated bucolic poet, was Pessoa's most complete depersonalization. Pessoa's heteronyms aligned with his poetic thoughts, that is, his understanding that

1 Sou mesmo o primeiro poeta a lembrar de que a Natureza existe. Os outros poetas têm cantado a Natureza subordinando-a a eles, como se eles fossem Deus; eu canto a Natureza subordinando-me a ela, porque nada me indica que sou superior a ela, visto que ela me inclui, que eu nasço dela e que (CAEIRO/ PESSOA, 2005, p. 180). poetry, that of the highest value, at least, should tend towards the dramatic. In one of his most famous theoretical texts, the Portuguese poet ranked the lyric poetry according to its dramatic quality. Some firstdegree lyric poetry would be the least dramatic type, according to Pessoa, since the verses and the poet's feelings would coincide; poetry would, then, be just the expression of a poet's feelings. Needless to say that this poetry should be regarded as some low-rank poetry, having no or little poetic value. Shakespeare was, on the other hand, highly valued, because his dramatic poetry, his tendency towards depersonalization, the creation of worlds and moods other than his own, should be the assessment criterion for all high-rank lyric poetry. But what if Hamlet was deprived of its action and dialogues? Deprived of the possibility of being enacted, of being a play? What would remain? Pessoa hints that quite possibly this is how his heteronyms should be understood, as the "drama-inpeople" they were: verses that begged for the erasure of the poet (as not having been written by Pessoa), being mere signatures, as they were not Pessoa's poems, but Álvaro de Campos', Alberto Caeiro's, Ricardo Reis' and many others'. A universe peopled with as many poets as depersonalization would allow. Hamlet without action, dialogues. Hamlet that could not be enacted, that is, deprived of its theatrical features; in other words, drama, drama-in-people, heteronyms.

Caeiro claims to be the greatest poet of all time, since he is the only one to have made an amazing discovery: that Nature exists. By setting himself apart from a tradition of poets, Caeiro seems to be establishing a new paradigm. The other heteronyms do not contradict such an assumption, and by calling Caeiro master, Reis, Campos and even Pessoa seem to agree that Caeiro's poems break away from a certain kind of tradition. But which one? Caeiro is "Greeker than the Greeks"2, says Reis and goes on to read his poems from the perspective of the paganism. Caeiro is the paganism, not some theory about a bygone

2 "mais grego que os gregos" (REIS/PESSOA, 1998, p. 112) 
belief, but the embodiment of a pagan worldview or existence, he adds. From Ricardo Reis' perspective, thus, Caeiro's poems, due to their total or absolute objectivity, disrupt Christianity tradition. Caeiro, nonetheless, never mentions the word paganism, he never theorizes, he just writes his natural poems as naturally as possible. But what kind of Nature is this one that he discovers?

Other poets submit Nature to their verses, as if they were Gods, Caeiro would say. He intends to invert this dynamic by submitting himself to Nature, subjugating himself to it, since there is nothing that proves he is, in fact, superior to it. Nature includes him. He comes from Nature. And by doing so, Caeiro is able to become another: a plant or any other natural thing. ${ }^{3} \mathrm{He}$ opens himself to different modes of feelings, or different sensations. By allowing himself to think with his eyes or with his ears, by being subjected to Nature, a plethora of sensations is made available and all his body is filled with sensations, modes of feelings, or metaphysics, as opposed to only one. ${ }^{4}$ And he can become the trees, the flowers, or even the movement of the wings of a butterfly. Caeiro's absolute or total objectivity, however, is threatened by the presence of thoughts. The poet knows that in order to become others in this eternal movement of depersonalization, in order to allow different metaphysics to take hold of his bodily sensations he needs to inhibit the act of thinking. Thinking would mean giving up on the possibility of seeing the world as it is - just the world without any prior conception, without any framework. Suspending the act of thinking enabled his original perceptions, as if he were seeing, touching, feeling for the very first time. And, without the interference

3 “...a capacidade única de Caeiro de tornarse outro, tornar-se planta, tornar-se coisa natural. A nãorelação torna possível não uma relação de união, mas um processo de devir."(GIL, 1999, p. 28)

4 E os meus pensamentos são todos sensações. Penso com os olhos e com os ouvidos E com as mãos e os pés E com o nariz e a boca (CAEIRO/PESSOA, 2005, p. 34) of thoughts, the experience was always an original one, always like the very first time, insofar as nothing in Nature was alike. There aren't two trees which are exactly the same, each one is unique, adds Caeiro, to the point that calling them trees seems harmful to the way we could apprehend the world. Language, therefore, damages our experience of the world as it tends to conceal differences. Even though there aren't two trees, or two rocks, or two birds that are exactly the same, our language, or our use of it, makes it seem so. The experience of language did not coincide with how he experienced the world. It was just language, incapable of grasping the complexities of Nature. Language was about language and not the world, as thinking was about the act of thinking and said nothing about the world itself. So was the thing-in-itself out of reach, as Kant had claimed? Are we still behind the line - the one that divided humans and non-humans? Is this still being modern?

Caeiro's absolute objectivity entailed the suppression of the subject. Suspending the act of thinking means thereby accessing other modes of knowledge rather than thoughts, rather than reason. A kind of knowledge the mind could not contain? For sure, something the mind could not control, as the mind wouldn't be the center of the experience anymore. Interestingly enough, acknowledging the non-human world, crossing the line, allowing for other types of experiences, would make Caeiro embody the paganism, being Greeker than the Greeks, positioning himself before the Great Divide. Even so Caeiro is the master of other modernist heteronyms. Caeiro is Fernando Pessoa's master, the greatest modernist Portuguese poet. The one, according to Massaud Moisés, to revolutionize Portuguese literature, modernize it. By being pagan? By forgetting "time's irreversible arrow"?

José Gil would say Caeiro's poems, even though apparently simple at first, are not an appeal to some past way of existence, quite the opposite, they result from the construction and the destruction of the European civilizations, from the experience of the war. As if all the past had been metamorphosed into 
the original view they portray, one that could only be due to the experience of Modernity. The seemingly naive perception of the world presented in his poems conceal their critical view. ${ }^{5}$ They conceal, I must add, that Modernity's wall had some cracks.

The term proposed in 2000 to name a new geological era by Paul Crutzen and Eugene Stoermer also reveals its alignment with Latour's thought: that the separation between human and non-human worlds was nothing but a fallacy. Crutzen and Stoermer proposed the term "Anthropocene" for a new era and dated it back to "James Watt's 1784 patent on the double-acting steam engine" (MENELY \& TAYLOR, 2017, p.3). That is, this very first version of the Anthropocene tells the story of the unintended consequences of human actions. A technological innovation by means of revolutionizing our mode of existence would then result in a catastrophic outcome. So far, however, consensus has not been reached regarding the beginning of this new geological era. 1784 or the postwar Great Acceleration, each date means the telling of a different narrative concerning the Anthropos and the consequences of their actions, from the perspective of agriculture, inventions, industrialization, capitalism and so on. All these narratives, nonetheless, have something in common: they present a new framework to conceive

5 A obra de Caeiro encontra-se com o olhar do primeiro homem, mas após a construção e a destruição das civilizações que se sucederam na Europa. Não houve que aprender e desaprender: ela é o resultado espontâneo de todo esse processo, reencontrando a visão da infância e da aurora da humanidade como se todos os olhares adultos da história se tivessem nela naturalmente metabolizado- ou seja, aprendidos e desaprendidos. Daí o peso crítico dessa poesia, o seu efeito revolucionário sobre os espíritos que dela se aproximam e por ela se deixarem impregnar; daí o facto de Caeiro ser capaz de escutar e compreender as mais finas sutilezas do pensamento especulativo (embora seja radicalmente distante dele. Como se houvesse um pensamento infantil a ser usado- também- pelos adultos). (GIL, 1999, p. 18). the human, one that shatters our claims and beliefs about Modernity and its founding concepts and conceptions.

First of all, "The ideabehind the term "Anthropocene" is that we have entered a new epoch in Earth's geological history, one characterized by the advent of the human species as a geological force" (SCRANTON, 2015, p. 17). For the very first time human beings are endowed with geological agency, which has two different implications that converge. One, being a geological force means that human beings are being regarded as a species. On an individual level no human has geological agency, which is one of the great paradoxes of facing the reality of climate change: what one does on an individual level has no or little effect in grappling with climate change. However, what each individual does matter. The second implication is that regarding humans as a geological force means that there is a nonhuman aspect to humans. Species or force, either way, the advent of the Anthropocene begs the revision of the idea of being human, inasmuch as we are no longer only human-human, but there is a non-human aspect to being human capable of altering the course of the planet, bringing about its total destruction.

This nonhuman, forcelike mode of existence of the human tells us that we are no longer simply a form of life that is endowed with a sense of ontology. Humans have a sense of ontic belonging. That is undeniable. We used that knowledge in developing both anticolonial (Fanon) and postcolonial criticism (Bhabha). But in becoming a geophysical force on the planet, we have also developed a form of collective existence that has no ontological dimension. Our thinking about ourselves now stretches our capacity for interpretive understanding. We need nonontological ways of thinking the human. (CHAKBRABARTY, 2012, p. 13)

Ironically, the intensification of The Great Divide 
that characterizes modernity, the separation between humans and non-humans, or even between subject and object. In other words, the intensification of subjectivity, the principle governing Modernity, led to the realization that both worlds were, in fact, intertwined. Human history and natural history are more enmeshed than Modernity had envisioned.

We are going through a contemporary crisis, from the historical standpoint. According to Dipesh Chakrabarty in the article The Climate of History: Four Theses, the humanistic distinction between human and natural history hadcollapsed. If Collingwood could conceive history as being distinguished from nature and Croce could claim that there was no world other than that of the humans', that is, the non-human world didn't deserve or didn't have any historiography; this point of view cannot be sustained when the nonhuman world is no longer immutable. The tsunamis, earthquakes, tornados, nature not subjugated by human subjectivity anymore (and this way not under control) reveal that human history cannot be understood or studied without its counterpart: natural history or non-human history. "The wall of separation between natural and human histories that was erected in early modernity and reinforced in the nineteenth century as the human sciences and their disciplines consolidated themselves has some serious and longrunning cracks in it"(CHAKRABARTY, 2012, p. 10). We have crossed the line, it seems.

The Anthropocene, as the unintended consequences of human actions, draws our attention to the interconnectedness of all life forms (MORTON, 2018, p. 36). If our modern assumptions, then, led to the seemingly uncontrollable crisis we are living in, one to bring about mass destruction, there is an urgent need to reconsider our thoughts on the so-called modern constitution. If our belief in "time's irreversible arrow" led to a catachronistic temporality, as Aravamudan would say, that is, to the experience of Enlightenment's reversibility (apocalyptic nightmares); a serious revision of human's relationship to the world around is begged. For 12,000 years, man have thought to have been "on top of things, outside of things or beyond things, able to look down and decide exactly what to do" (MORTON, 2018, p. 25); rephrasing Timothy Morton: subjectivity was the measure of all things. But, then, wasn't it Hegel's claim? That subjectivity shaped modernity? Wasn't it also what Latour said? That the advent of humanism was asymmetrical, since the nonhuman world was forgotten? However, the repressed returns, and with a vengeance.

Timothy Morton's adherence to object-oriented ontology and its claims that nothing can be accessed in its entirety and that thought is, by no means, the best access mode to things, is grounded in its usefulness in the age we are living in:

One way is that it doesn't make thinking, in particular human thinking, into a special kind of access mode that truly gets at what a thing is. OOO tries to let go of anthropocentrism, which holds that humans are the center of meaning and power (and so on). This might be useful in an era during which we need to at least recognize the importance of other lifeforms. (MORTON, 2018, xli)

Caeiro's and Timothy Morton's ideas, though decades apart, point to the need to reconceive the role of thinking, which is synonymous with the role of men. The mind that can control, the humanly acceptable knowledge, the one that subjugates the world under conceptions, prevents the apprehension of other life forms. "What matters isn't exactly what you think but how you think"(MORTON, 2018, p. 25). Going beyond the line that divides humans and non-humans is necessary to; at least, acknowledge the existence of this other world, not anthropocentrically-centered. Aravamudan would criticize Timothy Morton's Buddhist-like attitude, one that advocates that being ecological does not necessarily mean activism, but refers to relating to a non-human being for no reason at all (MORTON, 2018, p. 59):“By caring for strangers as well as plutonium (presumably we would caress the 
former but use radiation protection gloves to handle the latter) we might show a Levinasian commitment to radical alterity."(ARAVAMUDAN, 2013, p. 16). But wasn't that Latour's question? Where are the Lévinases of the animals? - he questions why because neither human nor non-human worlds could be understood, as long as humanism was still conceived as being opposed to the object (LATOUR, p. 136). One must go beyond the dichotomy, then.

What if we were not kept anthropocentrically safe in our assumptions and theories? What if Lévinas' hospitality could encompass the non-human world as well? And Heidegger's full-on, rich world could be granted to all life-forms, instead of just to humans? And Cavell's acknowledgment could refer to anything else other than other minds? What if theories that brought to surface modernity's frailties could be extrapolated to encompass the non-human world? Would we turn Wisdom into Folly?

One would be "Greeker than the Greeks", Ricardo Reis would probably answer. One would be the master of the "drama-in-people", insofar as the verses would embody the concept of depersonalization. It is no wonder then that after Caeiro's "apparition", Fernando Pessoa wrote down Chuva Oblíqua, almost as an attempt to make sure he could go back to being the poet he was, to make sure he hadn't lost his voice, style, way of thinking. Caeiro discovered Nature and in doing so he disclosed one of the greatest problems that would concern us living during the Anthropocene: the relationship between subject and object, the subjugation of the latter by the former and the need for depersonalization, i.e, the suppression of the subject.

Interestingly enough, Pessoa's "drama-in-people", the way by which he would revolutionize Portuguese Literature. By breaking away from the emotional tradition that had shaped Portuguese lyric poetry since its beginning, meant his depersonalization. That is, his conception of poetry would collide with any idea concerning a genius subject. In other words, the intensification of subjectivity, through its guiding principles of freedom and reflection, resulted in the experience of alterity. His famous verse "O que em mim sente 'stá pensando", that in a free translation would read as: that which in me feels is thinking, connected feeling with thought, meaning that a thought of a feeling corresponded to the feeling itself. There was nothing that separated feelings from thoughts, since feelings were also a mode of thinking. A poet, therefore, by combining feelings and thoughts, would have a multitude of modes of feelings available. This way, Pessoa could become Caeiro or others, by means of combining feelings and thoughts, by means of letting go of his own subjectivity. Thinking like another was feeling like another. No wonder would Pessoa criticize any attempt to explain his poems, heteronyms, pseudo-heteronyms by resorting to his biography. If there was any trace of himself in his poems, or any trace of his personal story or opinions that meant that he had failed as a poet. Modern poetry for him signified the erasure of the person, the subject. It is understandable why Caeiro is the master. He is the one to embody the extreme depersonalization experience, the confrontation with the ultimate otherness: that of nature. Not only does Caeiro acknowledge nature, but he is by it transformed. His and nature's history are intertwined. He lives in the mishmash of worlds.

At the end of the article The Catachronism of Climate Change, Srinivas Aravamudan, after identifying speculative materialism and objectoriented ontology as a wave of post-Heideggerian climate change philosophy, that abandons "humanist subjectivism for a democracy of the objects or "an alien phenomenology"'” (ARAVAMUDAN, 2013, p. 18), states that: "What began as catachronism, the burdensome experience of "living in the end times," could morph into the birth of many brave new worlds populated by those that come after the subject (...)" (ARAVAMUDAN, 2013, p.21). One cannot help wondering if this "after the subject" does not have a history, one to be traced back to the beginning of the twentieth century, when the idea of the subject was being questioned by modernist literature.

The relevance of the aesthetic experience lies, 
according to Timothy Morton, in shaping our experience in the Anthropocene, especially because any aesthetic experience means caring for what is nonhuman. An artwork poses the question of the solidarity with what is non-human, being the artwork ecological or not. Besides, the experience of beauty in itself is not subject-driven: "This is because beauty just happens, without our ego cooking it up. The experience of beauty itself is an entity that isn't me. This means that the experience has an intrinsic weirdness to it (MORTON, 2018 , p. 65). What happens when a not subject-driven experience is mediated by another not subject-driven experience? A real ecological experience? One can only wonder.

\section{References}

ARAMAVUDAN, Srinivas. "The Catachronism of Climate Change”. Diacritics, vol. 41, n. 3, 2013, pp. 6-30. DOI: 10.1353/ dia.2013.0019.

BAUCOM, Ian. "Postcolonial Method and Anthropocene Time". Cambridge Journal of Postcolonial Literary Inquiry, vol. 1, n. 1, 2014, pp. 123-142. DOI: 10.1017/pli.2013.13.

BENJAMIN, Walter. Charles Baudelaire um lírico no auge do capitalismo. $3^{\text {a }}$ ed. São Paulo: Brasiliense, 2000.

- Magia e técnica, arte e política: ensaios sobre literatura e história da cultura. 7ª ed. São Paulo: Brasiliense, 1996.

The origin of German tragic drama. London: Verso, 2003.

CAVELL, Stanley. Disowning Knowledge: In six plays of Shakespeare. New York: Cambridge University Press, 1987.

CHAKRABARTY, Dipesh. "Postcolonial studies and the Challenge of Climate Change". New Literary History, vol. 41, n.1, 2012, pp. 1-18. DOI: 10.1353/nlh.2012.0007.

. "The Climate of History: Four Theses". Critical Inquiry, vol. 35, n. 2, 2009, pp. 197-222. DOI: 10.1086/596640.

FOUCAULT, Michel. As palavras e as coisas. São Paulo: Martins Fontes, 2007.

GIL, José. Diferença e Negação na poesia de Fernando Pessoa. Lisboa: Relógio d'água, 1999.

HABERMAS, Jürgen. O discurso filosófico da Modernidade. São Paulo: Martins Fontes, 2002.

LATOUR. Bruno. We have never been modern. Cambridge: Harvard University Press, 1993.

MARTIN, Catherine Gimelli. Ruins of Allegory: Paradise Lost and the Metamorphosis of Epic Convention. Durham: Duke University Press, 1998.

MENELY, Tobias; TAYLOR, Jesse (eds.). Anthropocene reading. Pennsylvania: The Pennsylvania State University Press, 2017.

MILTON, John. Paradise Lost. Chicago: Encyclopaedia Britannica, 1952.

MORTON, Timothy. Being Ecological. Cambridge: The MIT Press, 2018

PESSOA, Fernando. Poesia Completa de Alberto Caeiro. São Paulo: Companhia das Letras, 2005 
Reading Alberto Caeiro's Poems with Anthropocene Eyes

Primeiro Fausto. São Paulo: Iluminuras, 1996.

.Obra Poética. Rio de Janeiro: Nova Aguilar, 2005

. Obras em Prosa. $1^{\text {a }}$ ed. Rio de Janeiro: Nova Aguilar, 1998.

. Tragédia Subjectiva. Rio de Janeiro: Nova Fronteira, 1991.

SCRANTON, Roy. Learning to die in the Anthropocene. San Francisco: City Lights Books, 2015. 